\title{
Annual Dynamics of Phytoplankton in the Black Sea in Relation to Wind Exposure
}

\author{
Vladimir Silkin *, Alexander S. Mikaelyan, Larisa Pautova and Alexey Fedorov
}

check for updates

Citation: Silkin, V.; Mikaelyan, A.S.; Pautova, L.; Fedorov, A. Annual Dynamics of Phytoplankton in the Black Sea in Relation to Wind Exposure. J. Mar. Sci. Eng. 2021, 9, 1435. https://doi.org/10.3390/ jmse9121435

Academic Editor: Carmela Caroppo

Received: 31 October 2021

Accepted: 9 December 2021

Published: 15 December 2021

Publisher's Note: MDPI stays neutral with regard to jurisdictional claims in published maps and institutional affiliations.

Copyright: (c) 2021 by the authors. Licensee MDPI, Basel, Switzerland. This article is an open access article distributed under the terms and conditions of the Creative Commons Attribution (CC BY) license (https:// creativecommons.org/licenses/by/ $4.0 /)$.
Department of Ecology, Shirshov Institute of Oceanology, Russian Academy of Sciences, 117997 Moscow, Russia; mikaelyan@ocean.ru (A.S.M.); larisapautova@ocean.ru (L.P.); aleksey_fedorov_199001@mail.ru (A.F.)

* Correspondence: vsilkin@mail.ru; Tel.: +7-918-200-7560

\begin{abstract}
Studies of the annual dynamics of phytoplankton in the NE Black Sea at two stations on the shelf and the continental slope were conducted in 2016, 2017, and 2019. The species composition of phytoplankton has not undergone significant changes compared to previous decades. The coccolithophore Emiliania huxleyi, small flagellates, and diatoms determined the abundance of phytoplankton; and diatoms, coccolithophores, and dinoflagellates determined the total biomass. The annual dynamics of the satellite-derived chlorophyll-a showed peaks in spring and autumn, and sometimes in summer. During the stratified water column period, strong winds in most cases led to a detectible increase in chlorophyll-a. The annual dynamics of phytoplankton followed the pattern: small diatoms (spring) $\rightarrow$ coccolithophores (late spring, early summer) $\rightarrow$ large diatoms (summer, autumn). Such a pattern was typical for the previous decades. Coccolithophores dominated in weak SE winds, diatoms in NE winds. The combined effect of sustained offshore wind and strong current can cause diatom blooms during stratified water, even if the wind velocity is moderate.
\end{abstract}

Keywords: phytoplankton; Black Sea; species composition; wind; diatoms; dinoflagellates; coccolithophores

\section{Introduction}

Marine phytoplankton play a decisive role in the functioning of the biological carbon pump, which is responsible for the transfer of atmospheric carbon to the deep layers of the ocean [1,2]. The ocean is the primary carbon depositor [3] and is an essential regulator of the planet's climate $[4,5]$. Atmospheric carbon dissolved in water is absorbed by phytoplankton during photosynthesis; as a result, organic compounds are synthesized, which determine the functioning of the organic pump. However, there are species of phytoplankton-coccolithophores, which, in addition to creating organic matter, convert inorganic carbon into calcite, forming the so-called carbonate pump. In the ocean, diatoms are mainly responsible for the first pump, and coccolithophores are responsible for the second [6-8]. Therefore, the dominance of one or another component of phytoplankton determines the nature of the biological pump. The annual dynamics of phytoplankton exhibit pronounced seasonality; there is a regular recurring change of dominants. Without identifying the regulators that determine the shift of dominants, it is impossible to understand the basic pattern of the formation of the phytoplankton structure. This task is not trivial since there are seasonal and interannual trends in structural changes in phytoplankton and many potential regulators. This problem can only be successfully resolved with the help of regular and long-term field and remote sensing studies of the annual dynamics of phytoplankton. Potential regulators of phytoplankton dynamics can be divided into abiotic and biotic. The first includes the nutrients concentration, irradiation, and turbulence. The consensus of opinion is that nitrogen limits production in marine ecosystems $[9,10]$. The classical concepts of regulating the annual dynamics of phytoplankton are based on the change of mixing regimes in the ocean and the associated vertical transport of nutrients [11]. Light intensity can also shift the structure of phytoplankton [12]. 
The central biotic regulators of phytoplankton structure and productivity are considered to be the pressure of herbivores [13-15] or the influence of viruses [16]. Recently, hypotheses have emerged that suggest a change in the structure of phytoplankton due to non-static predator-prey dynamics $[17,18]$.

However, climate change also significantly determines the structural and functional organization of phytoplankton [19]. Climate change is not just temperature change; it can change meteorological parameters, the most important of which is wind [20]. The wind speed regulates the intensity of the Ekman pumping, and the wind direction significantly impacts the nature and properties of macro- and mesoscale hydrodynamics. These physical processes determine the rate of flow of nutrients into the photic zone while simultaneously changing the depth of the seasonal thermocline and, as a result, the light regime in the upper mixed layer (UML) [21]. The structure of phytoplankton in the Black Sea is significantly determined by the speed and direction of the wind [22]. Therefore, long-term phytoplankton data need to be supplemented with data from meteorological observations.

The Black Sea is an inland body of water with a relatively weak influence from the ocean, affecting the sea's salinity, which does not exceed 19 on the surface [23]. The trophic status of this reservoir has a latitudinal zonality, $80 \%$ of river runoff is concentrated in the western part, which is the most eutrophicated [24-27]. In the eastern part, the phytoplankton biomass is significantly lower [28].

A feature of the hydrodynamics of the Black Sea is the presence of the Rim Current (RC), which runs along the periphery along the continental slope. It has a cyclonic circulation and forms the central Western and Eastern cyclonic gyres as well as mesoscale cyclonic and anticyclonic eddies along the slope [29-31]. The current speed of the RC ranges from 0.1 to $1 \mathrm{~m} \mathrm{~s}^{-1}$ and is determined by the intensity and direction of the winds. The dominant wind directions in the northeastern Black Sea are northeast and southeast [32].

Considerable data on the species composition, abundance dynamics, and biomass of phytoplankton have accumulated from the Black Sea. However, most of this material relates to the western part of the sea [33,34]. Studies conducted in the last century in the northeastern part of the Black Sea were episodic. The exception is the long-term observations of the structure of phytoplankton in Novorossiysk Bay [35]. There are two examples of annual surveys to study the structure of phytoplankton in coastal and adjacent waters near Gelendzhik [36] and Anapa [37]. These studies have shown that 2-3 peaks of phytoplankton abundance and biomass are observed in these areas. The first spring bloom is in February-March and is determined by the intensive growth of diatoms. The second bloom is in autumn, less powerful, and also associated with the growth of the diatoms. Sometimes there is a third peak both in bays and in the open sea due to the growth of either diatoms or dinoflagellates.

Studies of recent decades have shown that in the 2000s, there was a significant transformation of the structure of phytoplankton $[38,39]$. Spring blooms of diatoms have become less intensive; simultaneously, the role of the coccolithophore Emiliania huxleyi has increased, the blooms of which began to be recorded practically every year in late spring or early summer. The role of dinoflagellates has decreased, and all changes in the composition of dominants are now taking place within the framework of the "diatoms-coccolithophores" system $[40,41]$.

In addition, intensive autumn-winter growth of coccolithophores was recorded in the open waters in November-February $[33,42-44]$. Winter diatom bloom was observed in February [28].

Remote sensing methods based on measuring the concentration of chlorophyll-a (Chl) and particulate inorganic carbon (PIC) have significantly supplemented the possibility of the study of the seasonal changes and interannual trends of phytoplankton [45-48]. Algorithms for calculating the coccolithophore abundance from satellite data have been developed for the Black Sea [49], making it possible to differentiate diatom and coccolithophore blooms. However, these methods have limitations and work well with the support of ship observations. 
This work continues the previous studies of phytoplankton seasonal dynamics in the northeastern part of the Black Sea $[22,41]$. We analyze the annual dynamics of phytoplankton during three years. For the shelf and continental slope areas, we used field data on phytoplankton composition. For the area adjacent to the continental slope, we used $\mathrm{Chl}$ obtained from a satellite scanner. A distinctive feature of this work is the emphasis on meteorological factors, namely, the influence of wind speed and direction on the amount and structure of phytoplankton.

\section{Methods}

\subsection{Field Sampling}

Phytoplankton samples were collected on a standard section from Golubaya Bay (near the city of Gelendzhik) from the R/V Ashamba. Two stations were located above a sea bottom depth of 100 and $500 \mathrm{~m}$ (Figure 1). The number of sampling depths varied from 6 to 8 . The vertical distribution of phytoplankton down to a depth of $70 \mathrm{~m}$ was studied in layers: in the UML, the seasonal thermocline (ST), and sub-thermocline layer. A total of 251 phytoplankton bathometric samples were collected and processed. The CTD "Sea Bird" (Sea-Bird Electronics, Inc., Bellevue, WA, USA) was used for hydrophysical measurements. Water samples were collected using 5-L Niskin bathometers. Samples were fixed with neutralized formaldehyde, and the final concentration was $0.8-1.0 \%$. Samples were stored in the dark, at room temperature, for a minimum of two weeks and slowly decanted after that $[50,51]$. Species identification was based on cell morphology [52,53]. Species names were checked http:/ / www.algaebase.org and http:/ / www.marinespecies.org (accessed on 15 October 2021).

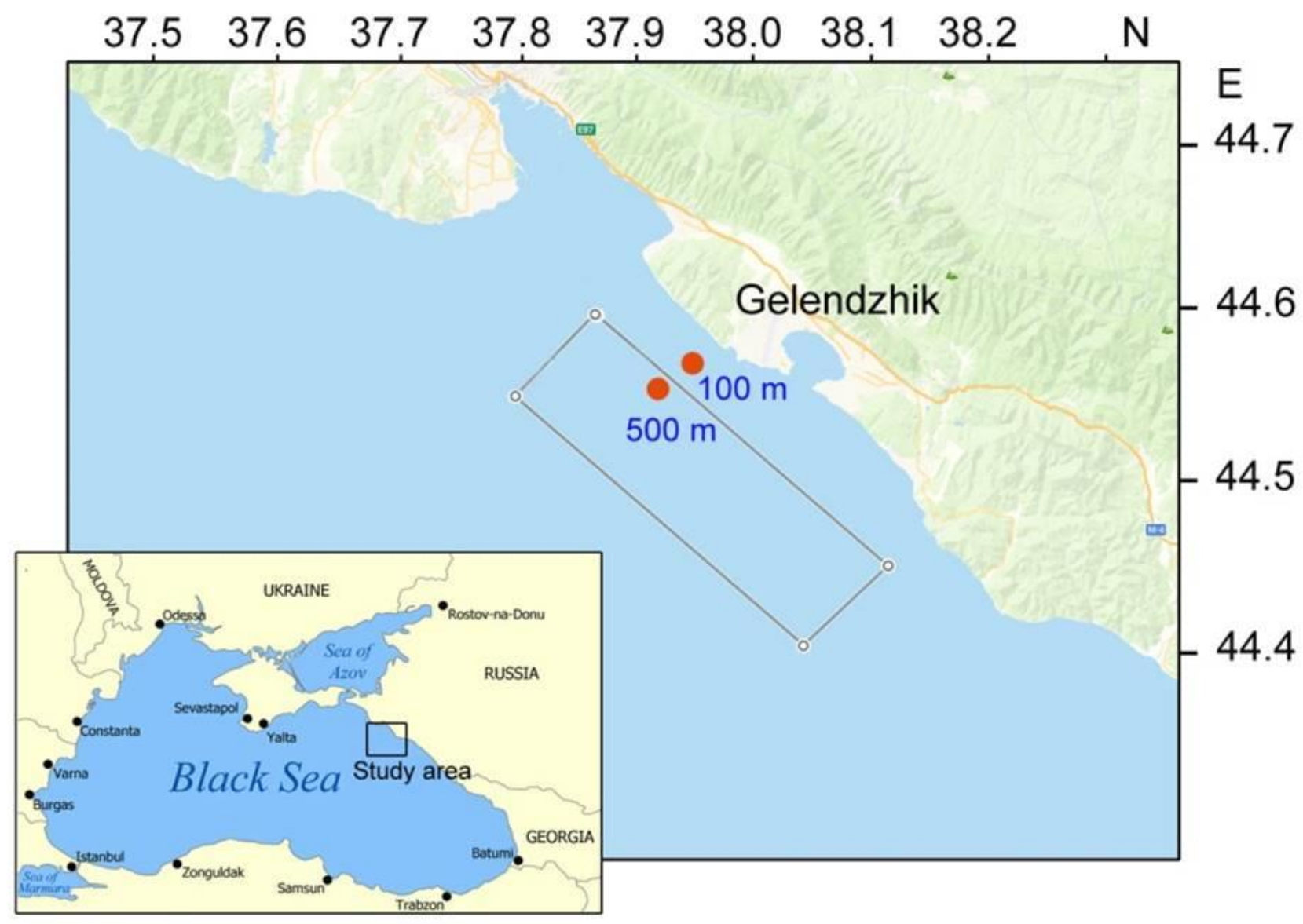

Figure 1. Map of the study area. The dots show the locations of two stations at $100 \mathrm{~m}$ and $500 \mathrm{~m}$. The rectangle shows the area for the satellite scanner's estimates of chlorophyll-a concentration. 
A method based on the geometric shape of cells was used to calculate biovolume [50,51,54]. Wet weight was calculated from the cell biovolume, assuming cell density was equal to $1 \mathrm{~g} \mathrm{~mL}^{-1}$. Biomass was expressed in units of wet weight $\left(\mathrm{mg} \mathrm{m}^{-3}\right)$. A species was considered dominant if its biomass was more than half of the total phytoplankton biomass at a given station. The second most biomass species was considered subdominant. The bloom level was taken as a cell abundance equal to $10^{6}$ cells L $^{-1}$, or a total phytoplankton biomass equivalent to $1000 \mathrm{mg} \mathrm{m}^{-3}$ [55].

\subsection{Remote Sensing Data}

To study the effect of wind on the growth of phytoplankton, data on the Chl were used. They were obtained using the MODIS-Aqua satellite scanner (http: / / cceancolor.gsfc. nasa.gov, accessed on 15 October 2021, 13, resolution $4 \mathrm{~km}$ ) in 2016, 2017, and 2019. We used 8-day composite images since such temporary averaging allows data to be available for most of the year, avoiding the problem of cloudy days. Chl measurements were carried out in a rectangular region located in the Gelendzhik area along the coast of the North Caucasus $\left(44^{\circ} 35.6^{\prime}(\mathrm{N}), 37^{\circ} 52.1^{\prime}(\mathrm{E}) ; 44^{\circ} 26.6^{\prime}, 38^{\circ} 06.7^{\prime} ; 44^{\circ} 23.8^{\prime}, 38^{\circ} 02.5^{\prime} ; 44^{\circ} 32.8^{\prime}, 37^{\circ} 48.0^{\prime}\right)$ at a distance of $4-5 \mathrm{~km}$ from the coast. This region is a continental slope.

The Black Sea is a region with a high concentration of organic matter that distorts the Chl signal. In this regard, several local algorithms have been developed to extract $\mathrm{Chl}$ from satellite images [56]. In the current study, we used an algorithm developed on the basis of Chl data collected in the northeastern part of the sea [57] where our study region was located:

$$
\mathrm{Chl}=0.354 \times \text { Chl_sat }-0.003
$$

where Chl_sat is the concentration of chlorophyll-a according to MODIS-Aqua images.

\subsection{Meteorological Data}

Data on wind speed and direction for the analysis of its effect on shelf phytoplankton were taken at the Gelendzhik meteorological station. For open waters, the data on wind speed were obtained from the Anapa meteorological station (http:/ / pogoda-service.ru, accessed on 15 October 2021). This station is located in a flat valley, which the North Caucasus does not shelter, and therefore more adequately reflects wind conditions in the open sea. To identify the dominant winds, progressive vector diagrams (PVD) were constructed using MATLAB 7.1.0, according to conventional methods [58].

\section{Results}

\subsection{Wind on the Shelf and Adjacent Area}

The main contribution to the wind on the shelf was made by the NE and SE winds (Table S1). The first determine the wave dynamics for most of the year, and they prevailed in the second half of the year. The second occur in March, April, and May. The wind regime usually changed in mid-June. In 2016, the E-SE winds became dominant in February; in June, the NE winds prevailed. In 2017, compared to 2016 and 2019, the overall repeatability of $\mathrm{E}, \mathrm{SE}$, and $\mathrm{W}$ winds was relatively high over the year; $\mathrm{N}$ and $\mathrm{NE}$ winds had less repeatability.

The highest wind speed was observed in January and February, 2016 and 2017; in 2019 , no storms were recorded. The lowest wind speed is usually in the summer. June 2017 was characterized by absolute windlessness, while in 2016, a wind of a relatively high intensity was recorded.

\subsection{Hydrological Structure}

In the winter months, when the air temperature is below the water temperature, the sea surface cools, and, as a result, vertical convection develops (Figure 2). In addition, storm winds contribute to intensive vertical mixing, recorded in the first two months. Usually, after mid-February, the sea surface warms up under the influence of an ever-increasing influx of solar radiation and warm air masses. The ST is formed usually in mid-March, 
separating the UML and the underlying colder and denser waters. In summer, there is a deepening of the lower border of the ST. This layer is broken down in late autumn, usually mid-November, due to the decrease in temperature and increasing wind-induced mixing.

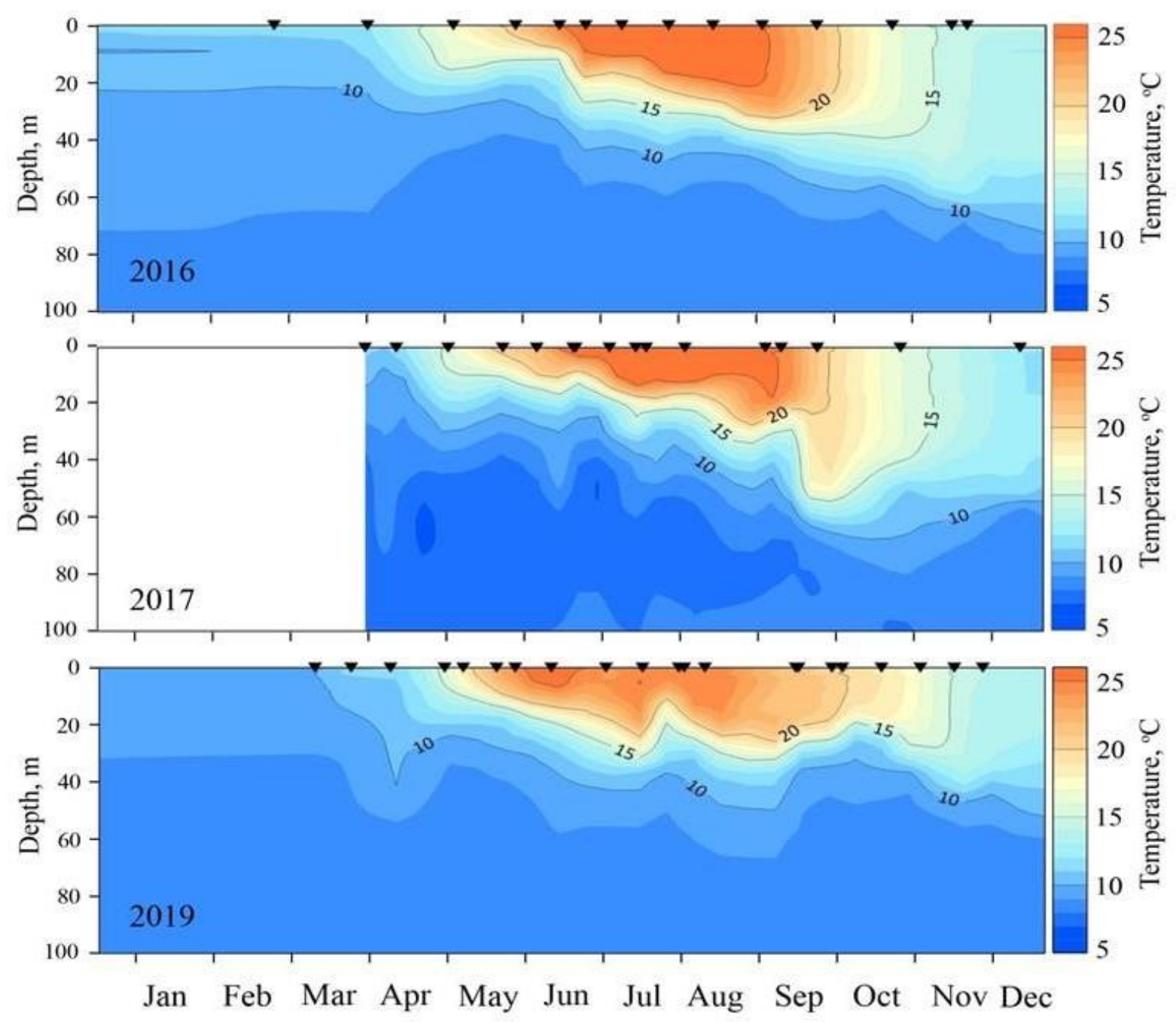

Figure 2. Vertical distribution of temperature at the station above a depth of $500 \mathrm{~m}$ in 2016, 2017, and 2019.

\subsection{Chl Dynamics in the Open Waters}

During three years of observations, Chl varied from maximum values in winter to minimum values in summer (Figure 3). The annual trend corresponded best to the seconddegree polynomial. This fit was good in $2016(\mathrm{r}=0.73)$ and $2019(0.84)$ and worse in 2017 (0.39). The latter could be due to the lack of data since it was cloudy for many 8-day periods. An annual trend line was used as a mean to estimate $\mathrm{Chl}$ anomalies, which were correlated with periods of strong wind exposure. 


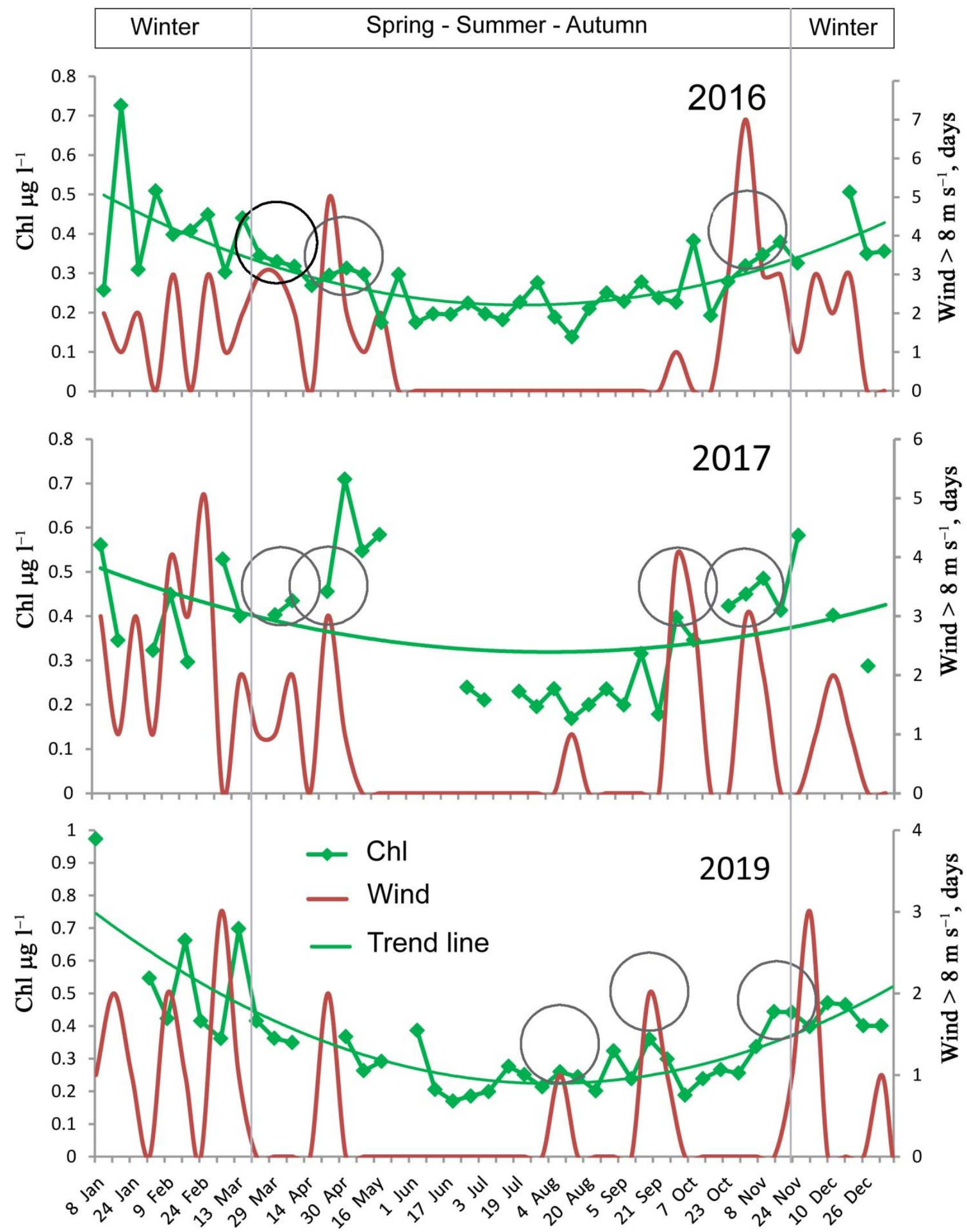

Figure 3. Seasonal dynamics of chlorophyll-a (Chl) concentration against the background of strong wind (number of days with wind $>8 \mathrm{~m} \mathrm{~s}^{-1}$ in an 8-day period) during 2016, 2017, and 2019. The trend line is a polynomial function. Vertical gray lines show the boundaries between hydrological periods with a non-stratified (winter) and stratified (spring, summer, autumn) water column. Cycles indicate the coincidence of strong wind effects and Chl increases above the annual trend line. 
Weak wind does not significantly increase turbulent mixing in the water column. To increase intensive mixing in the UML and pulsed turbulent mixing in the thermocline and below, a strong wind is required for a more or less long period. In this regard, we analyzed the duration of strong winds of more than $8 \mathrm{~m} \mathrm{~s}^{-1}$ during 8-day periods corresponding to the 8-day images of the Chl.

There are two fundamentally different hydrological seasons in the Black Sea with an unstratified (winter) and stratified (spring, summer, autumn) water column. Several strong wind events (from 3 to 4 ) were observed during the stratified period each year.

During each storm, an average daily wind speed of more than $8 \mathrm{~m} \mathrm{~s}^{-1}$ was observed for 1-7 days. In most cases (10 out of 12), Chl showed a positive anomaly (Figure 3, cycles). In two cases, in October 2016 and August 2017, a one-day storm coincided with a negative $\mathrm{Chl}$ anomaly. A correlation was found between the number of days with strong wind during 8-day periods and the Chl anomaly. It was weak, but significant ( $\mathrm{r}=0.3, n=84$, $p<0.005)$. In contrast to the stratified period, no correlation was found between these parameters in the unstratified period.

\subsection{Species Composition of Phytoplankton in the Shelf and Slope Areas}

In all years, phytoplankton was characterized by the same taxonomic composition (Tables 1 and 2). The high diversity of the community (up to 114 species) was formed primarily by dinoflagellates, which annually dominated the number of species (up to 72, $60-69 \%$ of the total number of species). The Protoperidinium genus was represented annually by a large number of species (up to 17). The interannual variations in the species composition of dinoflagellates were small-Jaccard index of similarity of the species structure reached $90 \%$.

Table 1. Taxonomic composition of phytoplankton abundance *.

\begin{tabular}{|c|c|c|c|c|c|c|}
\hline \multirow{2}{*}{ Taxon } & \multicolumn{2}{|c|}{2016} & \multicolumn{2}{|c|}{2017} & \multicolumn{2}{|c|}{2019} \\
\hline & $\mathbf{N}$ & $\%$ & $\mathbf{N}$ & $\%$ & $\mathbf{N}$ & $\%$ \\
\hline Bacillariophyceae & 14 & 18.9 & 27 & 23.7 & 25 & 27.5 \\
\hline Dinophyceae & 51 & 68.9 & 74 & 64.9 & 55 & 60.4 \\
\hline Prymnesiophyceae & 4 & 5.4 & 6 & 5.2 & 5 & 5.5 \\
\hline Cryptophyceae & 1 & 1.4 & 1 & 0.9 & 1 & 1.1 \\
\hline Dictyochophyceae & 3 & 4.0 & 4 & 3.5 & 3 & 3.3 \\
\hline Chlorophyceae & - & - & 1 & 0.9 & 1 & 1.1 \\
\hline Euglenophyceae & 1 & 1.4 & 1 & 0.9 & 1 & 1.1 \\
\hline Total & 74 & 100 & 114 & 100 & 91 & 100 \\
\hline
\end{tabular}

* N-number of species; \%-the proportion of total number of species.

In second place, in terms of number of species in all the years were diatoms (up to 27 species). The level of similarity of diatom species between the years was significantly lower-within $50 \%$. Interannual differences were mainly determined by variations in the number of randomly occurring planktonic species from the genera Navicula, Nitzschia, and Amphora. During the entire study period, the species of the genus Chaetoceros were not recorded in phytoplankton.

\subsection{Cells Abundance}

In all years, the abundance of phytoplankton was determined by the coccolithophore Emiliania huxleyi (April-early June), small flagellates with cells of 6-10 $\mu \mathrm{m}$ (June and August-September), and large centric diatom Pseudosolenia calcar-avis (summer maximum in July-August). (Table 2). The highest bloom of E. huxleyi over the slope was noted in June $2017\left(7.7 \times 10^{6}\right.$ cells $\left.\mathrm{L}^{-1}\right)$ at a depth of $5 \mathrm{~m}$. The minimum bloom of this

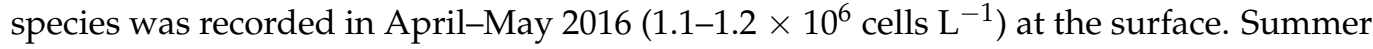
maximum abundance of $P$. calcar-avis differed significantly between years. The highest abundance of this species was recorded in August $2017\left(1.1 \times 10^{5}\right.$ cells L $\left.^{-1}\right)$. In other years, 
the abundance of $P$. calcar-avis was an order of magnitude lower $\left(1.0\right.$ and $2.1 \times 10^{4}$ cells L $^{-1}$ in July 2019 and June 2016, respectively), although it still prevailed in terms of biomass.

Table 2. Abundance (cells L ${ }^{-1}$ ) of dominant phytoplankton species in 2016, 2017, and 2019.

\begin{tabular}{|c|c|c|c|}
\hline Species & 2016 & 2017 & 2019 \\
\hline \multicolumn{4}{|c|}{ Dominants } \\
\hline $\begin{array}{l}\text { Small flagellates } \\
(\text { size } 6-10 \mu \mathrm{m})\end{array}$ & $2.1 \times 10^{6}$ June & $8.4 \times 10^{5}$ June & $\begin{array}{c}1.0 \times 10^{6} \text { June, } \\
\text { August, September }\end{array}$ \\
\hline Emiliania huxleyi & $\begin{array}{c}1.1-1.2 \times 10^{6} \\
\text { April-May }\end{array}$ & $7.7 \times 10^{6}$ June & $\begin{array}{l}3.3-3.7 \times 10^{6} \\
\text { May-June }\end{array}$ \\
\hline $\begin{array}{l}\text { Pseudosolenia } \\
\text { calcar-avis }\end{array}$ & $2.1 \times 10^{4}$ June & $1.1 \times 10^{5}$ August & $9.6 \times 10^{3}$ July \\
\hline $\begin{array}{l}\text { Pseudo-nitzschia } \\
\text { delicatissima }\end{array}$ & - & - & $1.1 \times 10^{6}$ May \\
\hline Proboscia alata & - & - & $1.8 \times 10^{3}$ September \\
\hline \multicolumn{4}{|c|}{ Sub-dominants } \\
\hline $\begin{array}{l}\text { Thalassionema } \\
\text { nitzschioides }\end{array}$ & $\begin{array}{c}\text { 6.4-6.1 × } 10^{3} \\
\text { June, September }\end{array}$ & $1.2 \times 10^{4}$ August & $3.4 \times 10^{3}$ May \\
\hline Cryptomonas sp. & - & $2.3 \times 10^{4}$ September & $3.6 \times 10^{4}$ June \\
\hline Gyrodinium fusiforme & $1.1 \times 10^{4}$ June & $1.0 \times 10^{3}$ August & $2.3 \times 10^{4}$ May \\
\hline Scrippsiella acuminata & $7.8 \times 10^{3}$ June & $2.2 \times 10^{3}$ August & $8.2 \times 10^{3}$ June \\
\hline Prorocentrum micans & $1.4 \times 10^{3}$ November & $1.2 \times 10^{3}$ July & $1.4 \times 10^{3}$ November \\
\hline Prorocentrum cordatum & $\begin{array}{c}2.4 \times 10^{2} \text { June, July, } \\
\text { September }\end{array}$ & - & $1.0 \times 10^{3}$ November \\
\hline Prorocentrum balticum & - & - & $4.4 \times 10^{3}$ May \\
\hline $\begin{array}{c}\text { Pseudo-nitzschia } \\
\text { delicatissima }\end{array}$ & $1.8 \times 10^{4}$ August & $3.6 \times 10^{4}$ August & - \\
\hline
\end{tabular}

As for other diatoms, the small pennate diatom Pseudo-nitzschia delicatissima was only recorded as the dominant species in May 2019. Its accumulations $\left(1.1 \times 10^{6}\right.$ cells $\left.\mathrm{L}^{-1}\right)$ were located at the lower boundary of the ST at a depth of $23 \mathrm{~m}$. Another centric diatom, the large-celled Proboscia alata, was noted as part of the dominant complex (both in abundance and biomass) at the end of September 2019 (Table 2).

\subsection{Biomass}

In all years, maxima of the total phytoplankton biomass were characteristic of the upper 25-0 m water layer (2017, 2019, and 2016, respectively). The two highest biomass were recorded in June $\left(1.4 \mathrm{~g} \mathrm{~m}^{-3}\right)$ and August 2017(1.6 $\mathrm{g} \mathrm{m}^{-3}$ ) (Figure 4). In June, high biomass was formed by Emiliania huxleyi, whose contribution to the total biomass reached 96.5\% (Figure 5). In August, the phytoplankton biomass was 98.5\% formed by the large diatom Pseudosolenia calcar-avis (Tables 3 and 4, Figures 3 and 4). In 2019, this pattern persisted-coccolithophores and P. calcar-avis made the main contribution to the formation of the maximum total biomass (E. huxleyi, 88-95\%, May-June; P. calcar-avis, 52\%, July). However, the community's biomass was lower this year than in 2017 during the bloom period of coccolithophores $\left(0.6-0.8 \mathrm{~g} \mathrm{~m}^{-3}\right)$ and during the growth of $P$. calcar-avis $\left(0.6 \mathrm{~g} \mathrm{~m}^{-3}\right)$ (Figure 4). 


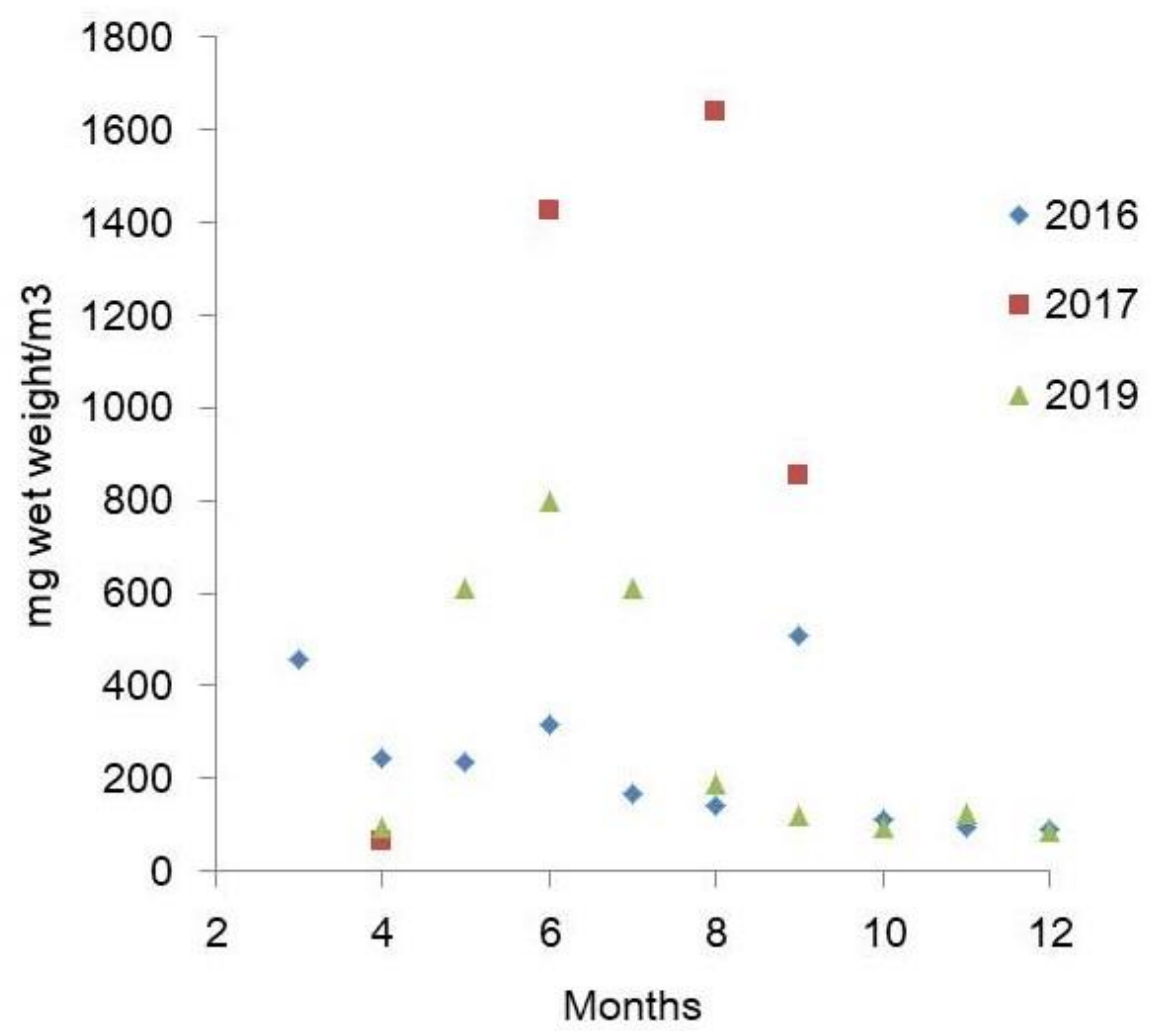

Figure 4. Dynamics of phytoplankton biomass in the NE the Black Sea at the station above a depth of $500 \mathrm{~m}$.

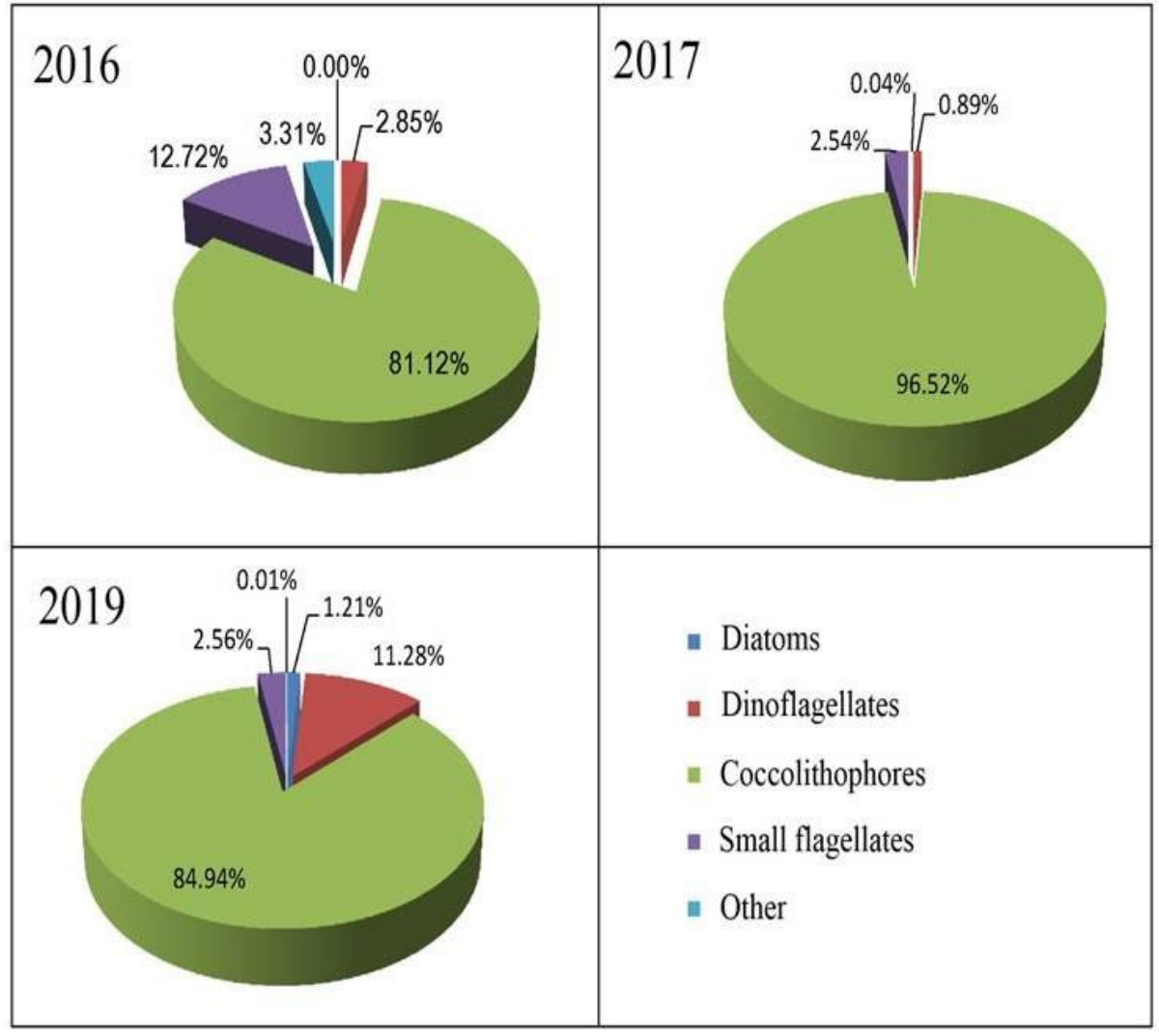

Figure 5. Taxonomic composition of phytoplankton biomass at the end of spring and in the early summer during the period of bloom of Emiliania huxleyi in 2016, 2017, and 2019. 
Table 3. Monthly maximum of the total biomass (B, $\mathrm{mg} \mathrm{m}^{-3}$ ) of phytoplankton in 2016, 2017, and 2019.

\begin{tabular}{cccccccccccc}
\hline Year & March & April & May & June & July & August & September & October & November & December \\
\hline 2016 & 456.3 & 245.9 & 236.6 & 317.4 & 166.3 & 143.4 & 506.8 & 110.8 & 95.3 & 92.0 \\
\hline 2017 & & 60.6 & & 1428.5 & & 1638.5 & 854.1 & & & \\
\hline 2019 & & 94.0 & 610.1 & 801.2 & 610.1 & 190.1 & 120.6 & 93.1 & 122.7 & 86.4 \\
\hline
\end{tabular}

Table 4. Contribution (\%) of diatoms, dinoflagellates, coccolithophores, and chrysophytes to the monthly maximum of the total phytoplankton biomass in 2016, 2017, and 2019. Values in bold show predominance of single species.

\begin{tabular}{|c|c|c|c|c|c|c|c|c|c|c|}
\hline Taxon & March & April & May & June & July & August & September & October & November & December \\
\hline \multicolumn{11}{|c|}{2016} \\
\hline Diatoms & 1.0 & 0 & 0 & 5.8 & 0.6 & 4.6 & 0.7 & 3.1 & 6.5 & 0.1 \\
\hline Dinoflagellates & 81.5 & 6.7 & 2.8 & 42.6 & 9.7 & 41.1 & 15.2 & 61.2 & 24.8 & 29.6 \\
\hline E. huxleyi & 9.0 & 89.7 & 81.1 & 36.6 & 72.9 & 10.9 & 0 & 7.9 & 44.1 & 50.8 \\
\hline $\begin{array}{l}\text { Dinobryon } \\
\text { balticum }\end{array}$ & - & - & - & - & - & - & 80.0 & - & - & - \\
\hline $\begin{array}{c}\text { Small } \\
\text { flagellates }\end{array}$ & 5.8 & 2.8 & 12.7 & 13.0 & 14.1 & 32.6 & 16.7 & 14.8 & 20.2 & 8.0 \\
\hline \multicolumn{11}{|c|}{2017} \\
\hline Diatoms & & 0 & & 0 & & 98.5 & 97.2 & & & \\
\hline Dinoflagellates & & 4.8 & & 0.9 & & 0.9 & 1.2 & & & \\
\hline E. huxleyi & & 82.5 & & 96.5 & & 0.3 & 13.0 & & & \\
\hline $\begin{array}{c}\text { Small } \\
\text { flagellates }\end{array}$ & & 11.8 & & 2.5 & & 0.5 & 1.3 & & & \\
\hline \multicolumn{11}{|c|}{2019} \\
\hline Diatoms & & 4.8 & 0.35 & 1.2 & 52.0 & 14.0 & 5.0 & 0.7 & 18.3 & \\
\hline Dinoflagellates & & 20.3 & 9.2 & 11.3 & 23.0 & 37.3 & 17.3 & 7.0 & 54.3 & \\
\hline E. huxleyi & & 36.8 & 87.8 & 84.9 & 17.7 & 24.4 & 29.0 & 74.5 & 4.6 & \\
\hline $\begin{array}{c}\text { Small } \\
\text { flagellates }\end{array}$ & & 38.0 & 2.6 & 2.6 & 7.2 & 27.0 & 48.6 & 17.7 & 29.2 & \\
\hline
\end{tabular}

In 2016, the maximum biomass was the lowest for all years $\left(0.46\right.$ and $0.5 \mathrm{~g} \mathrm{~m}^{-3}$ in March and September, respectively) (Table 3). This was associated with a weak bloom of Emiliania huxleyi and small cell size of Pseudosolenia calcar-avis. The leading role in the biomass was played by small dinoflagellates of the spring complex (up to $82 \%$ of the maximum total biomass, March) and chrysophyte Dinobryon balticum (80\%, September) (Table 4). As in 2017 and 2019, coccolithophores made a decisive contribution to the total biomass during their bloom period in April-May (up to 90\%). However, the contribution of P. calcar-avis was insignificant (5.8\%) during its maximum growth in June, whereas the bulk of the biomass was formed by dinoflagellates (42.6\%).

\subsection{Effect of Wind on Phytoplankton in the Slope Area}

Phytoplankton biomass and its taxonomical composition were associated with storm periods and moderate but frequent winds or their absence (Figure 6). In June 2017, the high biomass consisted mainly of coccolithophores (84\%). Before the sampling date of 7 June, daily winds were generally less than the 4 -month average $\left(4.3 \mathrm{~m} \mathrm{~s}^{-1}\right)$. In a highly stratified water column with a shallow UML (6 m), coccolithophores developed. The period of weak winds lasted from May to mid-July, which is confirmed by the prevalence of negative diurnal wind anomalies and a decrease in the cumulative sum of anomalies. After 15 July, 
there were several $3-5$ day periods with moderate wind $\left(5-7 \mathrm{~m} \mathrm{~s}^{-1}\right)$. The general increase in the influence of wind is reflected in the rise in the cumulative sum of wind anomalies. On 15 August, the depth of the UML increased to $13 \mathrm{~m}$ indicating the result of the windinduced mixing. Bloom of diatom Pseudosolenia calcar-avis was observed, which contributed $96 \%$ to the total phytoplankton biomass. After 22 August, the wind weakened, as evidenced by the decrease in the cumulative sum of wind anomalies. On 4 September, the depth of the UML was $20 \mathrm{~m}$. However, the bloom ended, and the biomass of phytoplankton was low, although diatoms composed the bulk of biomass (63\%).

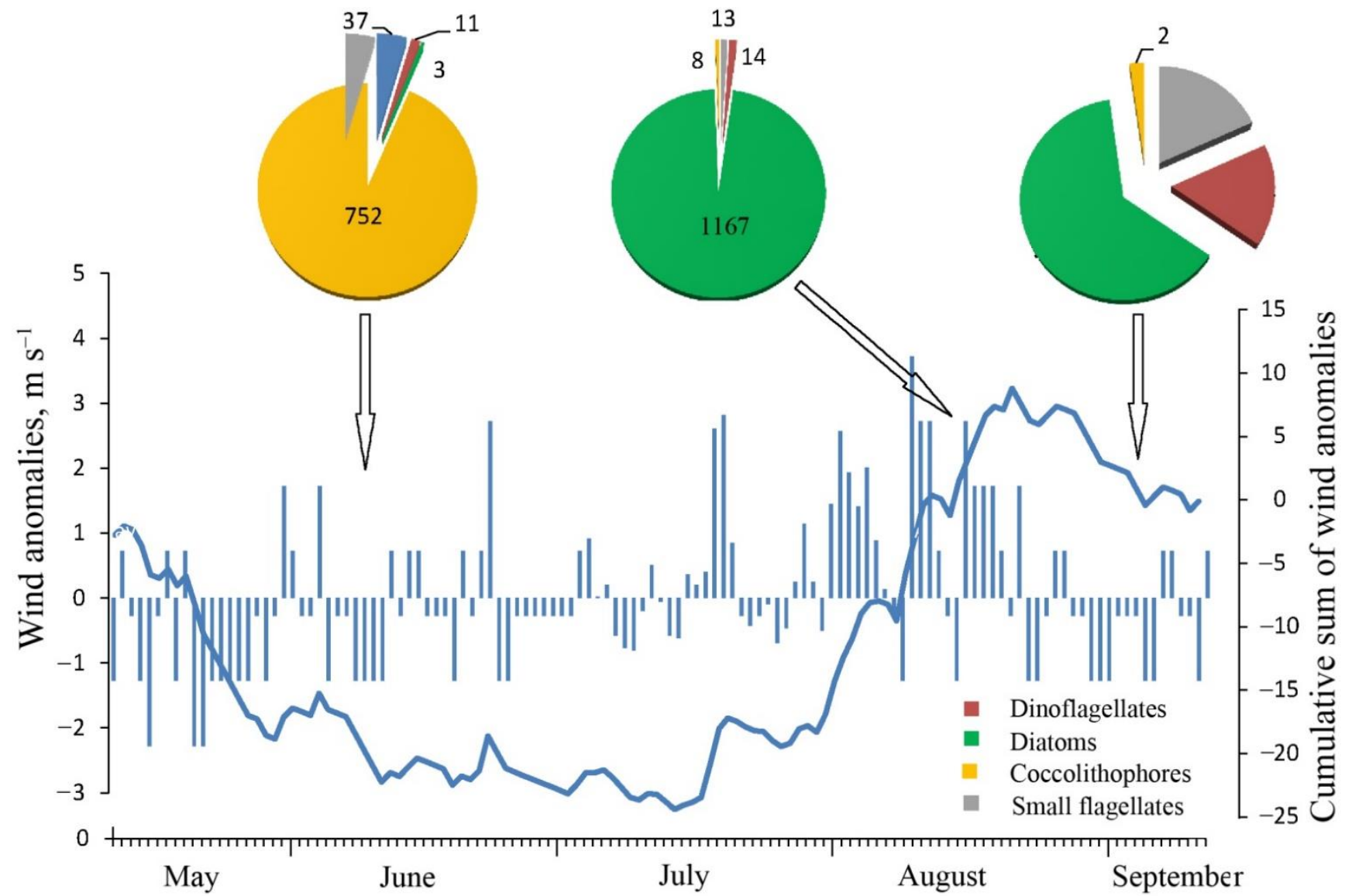

Figure 6. Daily wind anomalies from average speed for 4-month (bars) and cumulative sum of wind anomalies (line) during the period from 12 May to 12 September 2017. The diagrams show the average biomass $\left(\mathrm{mg} \mathrm{m}^{-3}\right)$ of the main groups of phytoplankton in the upper 10-m layer on 7 June, 15 August, and 4 September 2017 (data are shown by arrows).

\section{Discussion}

\subsection{Wind Effect on Annual Chl Dynamics}

There are two hydrological seasons in the Black Sea: unstratified and stratified. The most probable establishment of an ST (stratified period) occurs in mid-March, and its destruction (not stratified) in mid-November $[59,60]$.

The data on chlorophyll concentration obtained by remote sensing methods show that, in general, the annual dynamics followed a U-shaped curve with a peak in spring and autumn and a minimum in summer. This corresponds to other researchers' data in the Black Sea obtained using direct and remote observation methods [29,45,61].

In the stratified period of the year, the growth of phytoplankton in the euphotic zone is mainly limited by nutrients. Wind-induced mixing of the UML increases the erosion of the upper thermocline, which usually increases the concentration of nutrients in the UML. In addition, the kinetic energy of mixing penetrates the thermocline and below, increasing turbulent diffusion and upward flow of deep nutrients into the photic zone [62]. As a 
result, it promotes phytoplankton growth. However, this scheme works if the mixing is strong enough. In the Black Sea, a strong wind of more than $8 \mathrm{~m} \mathrm{~s}^{-1}$ with a total duration of 2-3 days per week determines the timing of the autumn bloom of phytoplankton [46]. In summer, the density gradients in the thermocline are the strongest. However, storms can destroy the thermocline. In July 2006, a strong 3-day wind of more than $10 \mathrm{~m} \mathrm{~s}^{-1}$ led to a deepening of the UML from $8 \mathrm{~m}$ to $22 \mathrm{~m}$ [63]. Our analysis showed that storms lasting from one to four days cause positive Chl anomaly in $83 \%$ of cases (Figure 2), which is in line with theoretical concepts.

It should be noted that our analysis was based on a rough comparison between a wind event and abiotic response. Eight-day periods may be too long or too short to detect an increase or decrease in Chl levels. For example, in some cases, the prominent rise in Chl was observed in the next period after the storm (Figure 3: April and October 2016, April 2017, and November 2017). Nevertheless, the obtained significant correlation between solid wind and $\mathrm{Chl}$ anomalies confirms the positive role of wind in stimulating the primary productivity of the basin during the period of water column stratification. It is known that very intense mixing during a powerful wind, such as a typhoon, dramatically increases the level of Chl $[63,64]$. It was previously shown that four successive storms in August 2015 caused an extreme bloom of phytoplankton in the Black Sea [43]. Our results showed that even a single period of strong winds regularly led to a detectible increase in Chl in the Black Sea. In the unstratified water period, the relationship between wind mixing and phytoplankton is reversed. During this period, the growth of phytoplankton is mainly limited by light. Thus, increasing the depth of the UML leads to a decrease in the cumulative illumination received by the cells and a decrease or prevention of phytoplankton growth. This follows from Sverdrup's fundamental Critical Depth Hypothesis [65].

Typically, the spring bloom of phytoplankton occurs at the end of winter, when convection stops and the formation of a seasonal thermocline reduces the depth of the UML. Sometimes, a near-surface bloom occurs before the appearance of a seasonal thermocline in the temporary upper layer, which forms if the wind is weak and mixing is suppressed [66,67]. In the Black Sea, due to strong vertical stratification, the phytoplankton bloom often occurs in winter. It was shown that calm weather in winter leads to creating a temporary thin upper layer in which phytoplankton grows. Strong winds also affect the spring bloom. For example, storms delay spring blooms on the Northwest European shelf [68]. Modeling has shown that increased wind mixing during the bloom period decreases its value in the polar and northern subtropical regions [69]. Although we did not find a significant negative relationship between solid winds and positive Chl anomaly for unstratified water, some examples show this pattern during the spring bloom period (Figure 3: February-early March 2016 and 2019).

\subsection{The Structure of Phytoplankton}

The taxonomic composition of phytoplankton in 2016, 2017, and 2019 did not change significantly compared to previous years. Diatoms and dinoflagellates made a decisive contribution to species diversity. Dinoflagellates were represented by the largest number of species, among which the genus Protoperidinium had the maximum number of species as in previous years [39]. A characteristic feature of the current research period was the complete absence of species from the genus Chaetoceros. In previous years, these species played a significant role in phytoplankton and were even dominant [22,39]. Since Chaetoceros species previously dominated phytoplankton in late spring at relatively high concentrations of nitrogen and silicate, their disappearance from phytoplankton may indicate changes in the hydrochemical regime.

The main role in the formation of phytoplankton abundance belonged to the coccolithophore Emiliania huxleyi; the maximum abundance was recorded in $2017\left(7.7 \times 10^{6} \mathrm{cells} \mathrm{L}^{-1}\right)$. This value is slightly lower than the maximum abundance $\left(8.2 \times 10^{6}\right.$ cells L $\left.^{-1}\right)$ recorded in 2004 (our data), which indicates the continued favorable conditions for growth of this 
species. It should be noted that the role of dinoflagellates in the formation of the subdominant complex has increased.

Phytoplankton biomass comprises mainly of three systematic groups-diatoms, coccolithophores, and dinoflagellates (Table 4). The role of dinoflagellates in the biomass has increased. The total phytoplankton biomass was determined by the growth of dinoflagellates in March and October 2016, and November 2019. In 2017, they did not play a significant role. The largest biomass was found in summer, and it was associated with the intensive growth of the large diatom Pseudosolenia calcar-avis. The maximum biomass of this species of $1.6 \mathrm{~g} \mathrm{~m}^{-3}$ was reached in August 2017. This value is almost two times lower than that we found earlier in August $2012\left(3.3 \mathrm{~g} \mathrm{~m}^{-3}\right)$. The maximum biomass of coccolithophores was registered at the beginning of June 2017, and it was also slightly lower than in the same season of 2004. In general, biomass values observed in the current research may indicate a trend of decreasing eutrophication of the NE Black Sea.

\subsection{Wind Regime}

In the Black Sea, hydrological structure is determined by two meteorological parameters, namely air temperature and wind direction and speed [70]. Wind and thermal atmospheric conditions are responsible for hydrophysical processes in the upper layers, namely the formation of the ST in the spring-summer-autumn period and its destruction in winter.

The wind regime observed in 2016, 2017, and 2019 did not differ significantly from previous years, as seen from the progressive vector diagram (Figure 7). From 2010 to 2015, the annual cycle was dominated by NE winds. The wind direction changes in the spring months. The interannual differences were in the shift of the timing of the change of the wind regime.

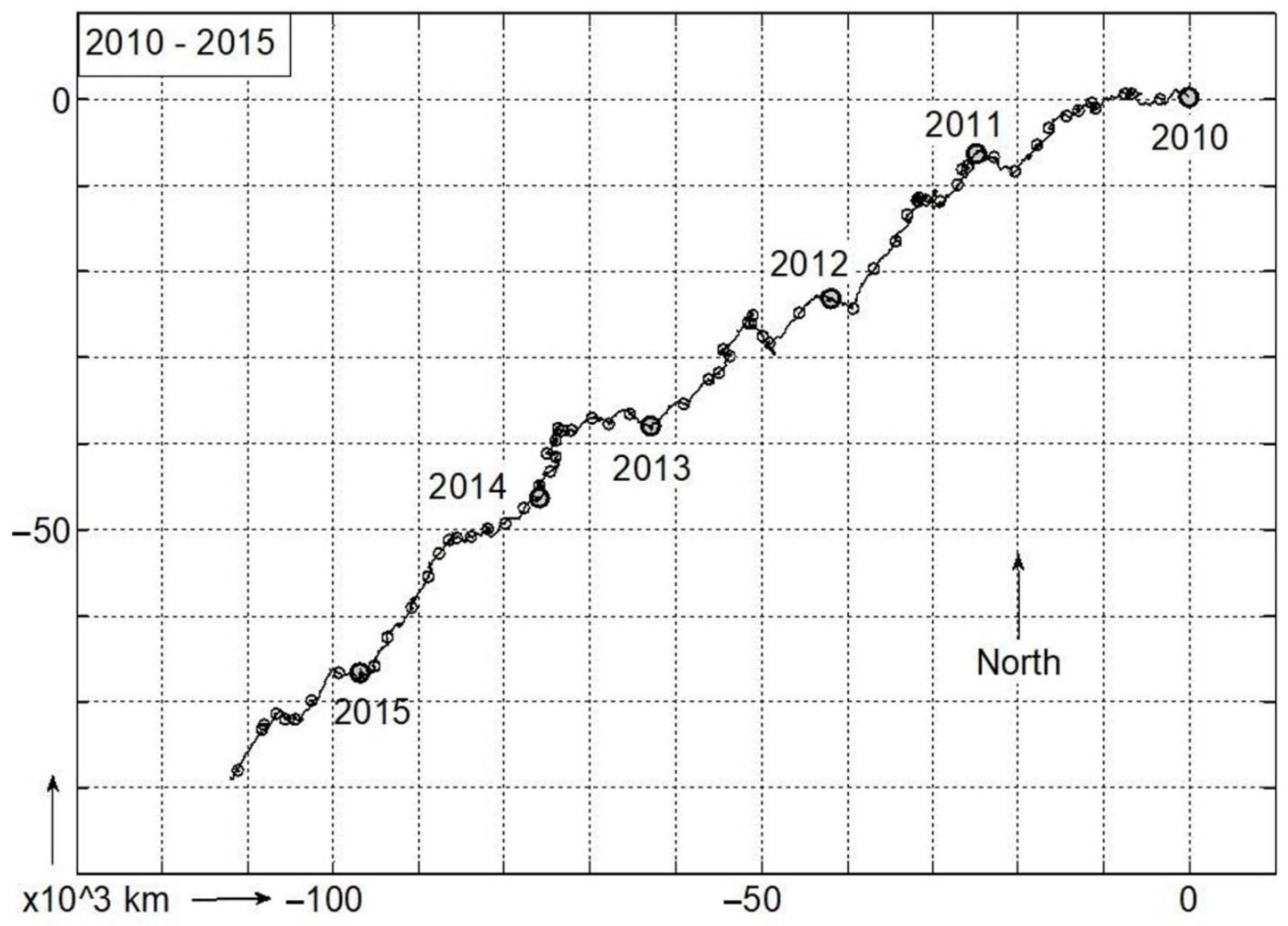

Figure 7. Progressive vector diagrams of the monthly averaged wind in the research area for the period 2010-2015. Vectors between dots show the prevailing wind direction. 


\subsection{Annual Dynamics of Phytoplankton}

The data obtained made it possible to identify the main pattern of the annual dynamics of phytoplankton. First of all, there are coccolithophores, which contribute mainly to biomass in late spring and early summer. The second and more productive component is large diatoms. Every year in summer and autumn, the large diatom Pseudosolenia calcar-avis causes the highest peak of phytoplankton biomass. Remote sensing shows that the most powerful peak in the $\mathrm{Chl}$ is observed every year in winter and early spring. Previous observations have shown that the small diatom Pseudo-nitzschia delicatissima develops in this period $[22,28]$. Thus, the annual dynamics of phytoplankton follows a pattern:

small diatoms (spring) $\rightarrow$ coccolithophores (late spring, early summer) $\rightarrow$ large diatoms (summer, autumn).

The first Chl maximum of the year associated with the bloom of small diatoms can be formed by different species depending on the place of sampling - bay, shelf, or open sea $[23,28,35,37,71,72]$. It was shown that over the past three decades, the pennate diatom Pseudo-nitzcshia delicatissima is the most likely contributing species [22,28]. To date, several hypotheses explain the launch of this spring bloom. The most widespread with the longest history is the Critical Depth hypothesis [65] (Sverdrup, 1953), which explains the absence of bloom during winter. It is follows that after the end of winter convective mixing, the depth of the UML becomes less than the compensation depth of population, when the growth rate is reached that exceeds the rate of total losses, bloom begins. This explains well the onset of bloom both in coastal waters and in the open ocean [73-75]. To date, there is criticism of this hypothesis, and a number of new hypotheses have been proposed, which are essentially some modifications of Sverdrup's theory [67,76-78]. The Pulse Bloom hypothesis is of particular interest since it explains bloom in winter and low biomass of small diatoms during spring bloom in the Black Sea [46]. Convective mixing and intense winds, usually recorded in January and February in the Black Sea [79], create supply of nutrients in the upper layers. The spring bloom begins at relatively high nitrogen and phosphorus concentrations and ends with a significant decrease, primarily in nitrogen concentration [22]. At the same time, the silicate concentration remains relatively high [22]. After the bloom of diatoms, the dominance passes to dinoflagellates, as was observed in March 2016. In April and May, phytoplankton biomass begins to be determined by coccolithophores, but they show maximum growth in late May and early June. Weak SE winds characterize this period; in June 2017, they were minimal, making it possible to raise the seasonal thermocline relatively high $(7-10 \mathrm{~m})$. In the UML, low nitrogen concentrations and a low nitrogen-phosphorus ratio (below the Redfield ratio) were observed at high silicate concentrations (up to $8 \mu \mathrm{M}$ ) [22]. This environment is a condition for accumulating of high biomass of coccolithophores in the UML, which was observed in 2017 and 2019 (Table 3, Figure 3).

Some hypotheses explain the dominance of large diatoms. They can be divided into biotic and abiotic factors. According to the first type of hypothesis, dominance is due to a narrowing of the spectrum of potential predators due to the size of large-celled diatoms compared to small-celled phytoplankton species [14,15,80]. In addition, the risk of virus attack on such large cells will likely be low [16]. However, this hypothesis cannot explain the complete absence of small diatoms, and why only one species remains in the community.

The central abiotic hypothesis states that large cells can accumulate nutrients and gradually use them in conditions of scarcity. Such species can dominate in the periodic provision of nutrients [22,81-84]. The weakness of this hypothesis is that such a mechanism can work for two-three cell generations (several days) [17], while the time between fluxes of nutrients may be longer. Indeed, during the dominance of large diatoms, the frequency of wind pumping can be more than one week. In all the years studied, the character interval between storms in the stratified period was $2-4$ weeks (Figure 3). 
In a dynamic environment with a deep thermocline, the light intensity varies widely from photoinhibition level in the near-surface layer of water to light limitation at the ST lower boundary. According to another hypothesis, large diatoms can change the specific light absorption coefficient due to moving chloroplasts [12]. This ability allows them to change the amount of energy absorbed depending on the intensity of the light. A low light absorption coefficient in near-surface waters avoids the destruction of chloroplasts; a high coefficient makes it possible to absorb light at low light fluxes effectively. This mechanism seems to be one of the main reasons for predominating large diatoms in the summer-autumn period. Another essential condition is an increased flow of deep nutrients to the photic zone due to intense mesoscale dynamics in these seasons [85].

Our data show that the dynamics of $\mathrm{Chl}$ were the opposite to the dynamics of the phytoplankton biomass (Figures 2 and 3). In summer, we observed the lowest $\mathrm{Chl}$ while the biomass was at its maximum. This is due to two factors. The first is the absorption of light by the cell depending on cellular $\mathrm{Chl}$ and the cell size $[86,87]$. With an increase in cell size, the relative cellular Chl decreases $[88,89]$ while the ratio of the carbon-chlorophyll ratio increases [90]. Secondly, the absorption of light by the cell is determined by the so-called package effect; it is associated with self-shading [91,92]; with an increase in cell size, the package effect reduces the specific light absorption coefficient [93]. These dependencies indicate that the satellite-derived $\mathrm{Chl}$ does not correctly reflect the annual dynamics of phytoplankton biomass in the Black Sea [90], where the summer growth of large diatoms results in a high total phytoplankton biomass.

\subsection{Wind Effect on Annual Dynamics of Phytoplankton}

The decisive influence of strong winds on the intensive mixing of the UML is well known, which, as a rule, leads to enrichment with nutrients that stimulate the growth of phytoplankton. Strong winds determine the timing of the autumn bloom of phytoplankton $[46,66]$. During the period of water stratification, typhoons and strong storms cause the development of phytoplankton $[63,64]$. The effect of moderate winds or calm has been less studied. In the Black Sea, May-June is the most windless month. This pattern is illustrated by wind statistics in 2017 (Figure 6). This period is favorable for the growth of coccolithophores, which is observed every year and is associated with strong stratification and low nitrogen concentration [22,41]. Thus, the absence of storms determines the conditions for the predominance of coccolithophores in phytoplankton during this period of annual succession (Figure 5).

The increase in the average wind velocity in the second half of summer is not associated with an increase in the frequency of storms (Figure 3). However, the cumulative effect of moderate wind mixing can cause the bloom of diatoms (Figure 6). In addition, prolonged exposure to wind increases the Rim Current velocity [70]. The higher speed of current increases turbulent diffusion, which enhances the upward fluxes of deep nutrients. Wind direction is also crucial in the shelf-slope area. In July-August, $45-55 \%$ of the winds were in the northeastern direction. This offshore direction may cause an upwelling of deep water along the continental slope and shelf. For example, in August 1978, a strong northeastern wind resulted in the bloom of diatoms in the slope area [36]. In July-August, the average wind velocity in $2017\left(4.43 \pm 0.25 \mathrm{~m} \mathrm{~s}^{-1}\right)$ was not significantly higher than that in $2016\left(4.04 \pm 0.13 \mathrm{~m} \mathrm{~s}^{-1}\right)$ and $2019\left(4.16 \pm 0.2 \mathrm{~m} \mathrm{~s}^{-1}\right)$. However, combined with the cumulative effect of long-term exposure in an area with strong currents and offshore direction, moderate winds can cause severe algal blooms, as was the case in August 2017 (Figure 6).

\section{Conclusions}

Three-year studies of the annual dynamics of phytoplankton in the northeastern part of the Black Sea have shown:

1. The species composition of phytoplankton has not undergone significant changes compared to previous years. The phytoplankton numerical abundance was deter- 
mined by coccolithophore Emiliania huxleyi, small flagellates, and diatoms. Diatoms, coccolithophores, and dinoflagellates formed the biomass.

2. The annual dynamics of satellite-derived Chl followed a U-shaped curve with a minimum in summer. Chl peaks are recorded in spring and autumn, and sometimes in summer. During the stratified water column period, strong winds regularly lead to a detectible increase in Chl. In the unstratified water period, a relationship between wind mixing and the amount of phytoplankton was not found.

3. The annual dynamics of phytoplankton had the following pattern: small diatoms (spring) $\rightarrow$ coccolithophores (late spring, early summer) $\rightarrow$ large diatoms (summer, autumn). Such a pattern was typical for the previous decades.

4. The combined effect of sustained offshore wind and strong current may cause bloom of diatoms during the stratified water period, even if the wind velocity is moderate.

Supplementary Materials: The following are available online at https: / www.mdpi.com/article / 10.3390 /jmse9121435/s1, Table S1: Monthly and annual wind frequency for the periods 2016, 2017, and 2019.

Author Contributions: V.S. conceptualized and wrote the paper; A.S.M. analyzed remote sensing data and wrote the paper; L.P. provided the field data and wrote the paper; A.F. conducted field studies. All authors have read and agreed to the published version of the manuscript.

Funding: Ministry of Science and Higher Education of the Russian Federation (theme No. 0128-20210013), Analysis of influence of wind on phytoplankton-Russian Science Foundation grant (project No. 20-17-00167); Analysis of seasonal changes of phytoplankton - the Russian Foundation for Basic Research (project No. 19-05-50090).

Institutional Review Board Statement: Not applicable.

Informed Consent Statement: Not applicable.

Conflicts of Interest: The authors declare that they have no known competing financial interest or personal relationships that could have appeared to influence the work reported in this paper.

\section{References}

1. Volk, T.; Hoffert, M.I. Ocean carbon pumps: Analysis of relative strengths and efficiencies in ocean-driven atmospheric $\mathrm{CO}_{2}$ changes. In The Carbon Cycle and Atmospheric $\mathrm{CO}_{2}$ Natural Variations Archean to Present; Geophysical Monograph Series; Sundquist, E.T., Broecker, W.S., Eds.; American Geophysical Union: Washington, DC, USA, 1985; Volume 32, pp. 99-110.

2. Sarmiento, J.L.; Gruber, N. Ocean Biogeochemical Dynamics; Princeton University Press: Princeton, NJ, USA, $2006 ;$ p. 526.

3. Le Quéré, C.; Andrew, R.M.; Friedlingstein, P.; Sitch, S.; Hauck, J.; Pongratz, J.; Pickers, P.A.; Korsbakken, J.I.; Peters, G.P.; Canadell, J.G.; et al. Global Carbon Budget 2018. Earth Syst. Sci. Data 2018, 10, 2141-2194. [CrossRef]

4. Field, C.B.; Behrenfeld, M.J.; Randerson, J.T.; Falkowski, P. Primary production of the biosphere: Integrating terrestrial and oceanic components. Science 1998, 281, 237-240. [CrossRef] [PubMed]

5. Falkowski, P.; Scholes, R.J.; Boyle, E.; Canadell, J.; Canfield, D.; Elser, J.; Gruber, N.; Hibbard, K.; Högberg, P.; Linder, S.; et al. The Global Carbon Cycle: A Test of Our Knowledge of Earth as a System. Science 2000, 290, 291-296. [CrossRef] [PubMed]

6. Smetacek, V. Diatoms and the ocean carbon cycle. Protist 1999, 150, 25-32. [CrossRef]

7. Buesseler, K.O.; Michael, P.; Livingston, H.D.; Cochrant, K. Carbon and nitrogen export during the JGOFS North Atlantic Bloom Experiment estimated from 234Th:238U disequilibria. Deep Sea Res. 1992, 39, 1115-1137. [CrossRef]

8. Milliman, J.D. Production and accumulation of calcium carbonate in the ocean: Budget of a non-steady state. Glob. Biogeochem. Cycles 1993, 7, 927-957. [CrossRef]

9. Ryther, J.N.; Dunstan, W.M. Nitrogen, phosphorus, and eutrophication in the coastal marine environment. Science 1971, 171, 1008-1013. [CrossRef]

10. Hecky, R.E.; Kilham, P. Nutrient limitation of phytoplankton in freshwater and marine environments: A review of recent evidence on the effects of enrichment. Limnol. Oceanogr. 1988, 33, 796-822. [CrossRef]

11. Barton, A.D.; Lozier, M.S.; Williams, R.G. Physical controls of variability in North Atlantic phytoplankton communities. Limnol. Oceanogr. 2014, 60, 181-197. [CrossRef]

12. Silkin, V.A.; Fedorov, A.V.; Flynn, K.J.; Paramonov, L.E.; Pautova, L.A. Protoplasmic streaming of chloroplasts enables rapid photoacclimation in large diatoms. J. Plankton Res. 2021, 43, 831-845. [CrossRef]

13. Kiørboe, T. A Mechanistic Approach to Plankton Ecology; Princeton University Press: Princeton, NJ, USA, 2008 ; p. 224.

14. Kiørboe, T. How zooplankton feed: Mechanisms, traits and trade-offs. Biol. Rev. Cam. Phil. Soc. 2011, 86, 311-339. [CrossRef] 
15. Ward, B.A.; Dutkiewicz, S.; Jahn, O.; Follows, M.J. A size-structured food-web model for the global ocean. Limnol. Oceanogr. 2012, 57, 1877-1891. [CrossRef]

16. Flynn, K.J.; Kimmance, S.A.; Clark, D.R.; Mitra, A.; Polimene, L.; Wilson, W.H. Modelling the effects of traits and abiotic factors on viral lysis in phytoplankton. Front. Mar. Sci. 2021, 8, 667184. [CrossRef]

17. Behrenfeld, M.J.; Halsey, K.H.; Boss, E.; Karp-Boss, L.; Milligan, A.J.; Peers, G. Thoughts on the evolution and ecological niche of diatoms. Ecol. Monogr. 2021, 91, e01457. [CrossRef]

18. Behrenfeld, M.J.; Boss, E.; Halsey, K.H. Phytoplankton community structuring and succession in a competition-neutral resource landscape. ISME Commun. 2021, 1, 12. [CrossRef]

19. Falkowski, P.G.; Oliver, M.J. Mix and match: How climate selects phytoplankton. Nat. Rev. Microbiol. 2007, 5, 813-819. [CrossRef] [PubMed]

20. Young, R.; Zieger, S.; Babani, A.V. Global Trends in Wind Speed and Wave Height. Sci. Vol. 2011, 332, 451-455. [CrossRef]

21. Mikaelyan, A.S.; Zatsepin, A.G.; Kubryakov, A.A. Effect of Mesoscale Eddy Dynamics on Bioproductivity of the Marine Ecosystems (Review). Phys. Oceanogr. 2020, 27, 590-618. [CrossRef]

22. Silkin, V.A.; Pautova, L.A.; Giordano, M.; Chasovnikov, V.K.; Vostokov, S.V.; Podymov, O.I.; Pakhomova, S.V.; Moskalenko, L.V. Drivers of phytoplankton blooms in the northeastern Black Sea. Mar. Poll. Bull. 2019, 138, 274-284. [CrossRef]

23. Sorokin, Y.I. The Black Sea Ecology and Oceanography; Backhuys Publishers: Leiden, The Netherlands, $2002 ;$ p. 875.

24. Bodeanu, N.; Andrei, C.; Boicenco, L.; Popa, L.; Sburlea, A. A new trend of the phytoplankton structure and dynamics in the Romanian marine waters. Cercet. Mar. 2004, 35, 77-86.

25. Moncheva, S.; Petrova-Karadjova, V.; Palasov, A. Harmful algal blooms along the Bulgarian Black Sea coast and possible patterns of fish and zoobenthic mortalities. In Harmful Marine Algal Blooms; Lavoisier Publ. Incorp: Paris, France, 1995; pp. 193-198.

26. Moncheva, S.; Gotsis-Skretas, O.; Pagou, K.; Krastev, A. Phytoplankton Blooms in Black Sea and Mediterranean Coastal Ecosystems Subjected to Anthropogenic Eutrophication: Similarities and Differences. Estuar. Coast. Shelf 2001, 53, 281-295. [CrossRef]

27. Velikova, V.; Moncheva, S.; Petrova, D. Phytoplankton dynamics and Red Tides (1987-1997) in the Bulgarian Black Sea. Water Sci. Technol. 1999, 39, 27-36. [CrossRef]

28. Mikaelyan, A.S. Winter bloom of diatom Nitzschia delicatula in the open waters of the Black Sea. Mar. Ecol. Prog. Ser. 1995, 129, 241-251. [CrossRef]

29. Oğuz, T.; Deshpande, A.G.; Malanotte-Rizzoli, P. The role of mesoscale processes controlling biological variability in the Black Sea coastal waters: Inferences from SeaWIFS-derived surface chlorophyll field. Cont. Shelf Res. 2002, 22, 1477-1492. [CrossRef]

30. Zatsepin, A.G.; Baranov, V.I.; Kondrashov, A.A.; Korzh, A.O.; Kremenetskiy, V.V.; Ostrovskii, A.G.; Soloviev, D.M. Submesoscale Eddies at the Caucasus Black Sea Shelf and the Mechanisms of Their Generation. Oceanology 2011, 51, 554-567. [CrossRef]

31. Kubryakov, A.A.; Stanichny, S.V.; Zatsepin, A.G.; Kremenetskiy, V.V. Long-Term Variations of the Black Sea Dynamics and Their Impact on the Marine Ecosystem. J. Mar. Syst. 2016, 163, 80-94. [CrossRef]

32. Krivosheya, V.G.; Moskalenko, L.V.; Melnikov, V.A.; Skirta, A.Y. Effects of the Wind and Thermal Conditions Variability on the Structure and Dynamics of the Seawater in the Northeastern Black Sea. Oceanology 2012, 52, 453-466. [CrossRef]

33. Belogorskaya, E.V.; Kondratieva, T.M. The Distribution of the Phytoplankton in the Black Sea. Studies of the Plankton of the Black Sea and the Asov Sea; Naukova Dumka: Kiev, Ukraine, 1965; pp. 36-58. (In Russian)

34. Georgieva, L.V. Phytoplankton. Species composition and dynamics. In Plankton of the Black Sea; Kovalev, A.V., Finenko, Z.Z., Eds.; Naukova Dymka: Kiev, Ukraine, 1993; pp. 31-55. (In Russian)

35. Mashtakova, G.P.; Roukhiyainen, M.I. Seasonal dynamics of phytoplankton. In Basis of Productivity in the Black Sea; Greeze, V.N., Ed.; Naukova Dumka: Kiev, Ukraine, 1979; pp. 85-87. (In Russian)

36. Zernova, V.V.; Nezlin, N.P. Seasonal changes in phytoplankton in the north-eastern part of the Black Sea during 1978. In Seasonal Changes in Plankton of the Black Sea; Vinogradov, M.E., Ed.; Nauka: Moscow, Russia, 1983; pp. 12-25. (In Russian)

37. Vershinin, A.; Moruchkov, A.; Sukhanova, I.; Kamnev, A.N.; Pankov, S.; Morton, S.; Ramsdell, J. Seasonal changes in coastal phytoplankton at Bolšoj Utriš (northeast Black Sea) in 2001-2002. Oceanology 2004, 44, 399-405.

38. Mikaelyan, A.S.; Pautova, L.A.; Pogosyan, S.I.; Suchanova, I.N. Summer bloom of coccolithophorids in the northeastern Black Sea. Oceanology 2005, 45, 127-138.

39. Pautova, L.A.; Mikaelyan, A.S.; Silkin, V.A. The structure of plankton community in shelf waters of north-eastern part of the Black Sea in the period of mass bloom of Emiliania huxleyi in 2002-2005. Oceanology 2007, 47, 408-417. [CrossRef]

40. Silkin, V.A.; Pautova, L.A.; Pakhomova, S.V.; Lifanchuk, A.V.; Yakushev, E.V.; Chasovnikov, V.K. Environmental control on phytoplankton community structure in the NE Black Sea. J. Exp. Mar. Biol. Ecol. 2014, 461, 267-274. [CrossRef]

41. Mikaelyan, A.S.; Pautova, L.A.; Chasovnikov, V.K.; Mosharov, S.A.; Silkin, V.A. Alternation of diatoms and coccolithophores in the northeastern Black Sea: A response to nutrient changes. Hydrobiologia 2015, 755, 89-105. [CrossRef]

42. Sukhanova, I.N. The phenomenon of mass bloom of coccolitophorids in late autumn period in the Black Sea. RAS Rep. 1995, 340, 256-259. (In Russian)

43. Kubryakov, A.A.; Zatsepin, A.G.; Stanichny, S.V. Anomalous summer-autumn phytoplankton bloom in 2015 in the Black Sea caused by several strong wind events. J. Mar. Syst. 2019, 194, 11-24. [CrossRef]

44. Kubryakova, E.A.; Kubryakov, A.A.; Mikaelyan, A.S. Winter coccolithophore blooms in the Black Sea: Interannual variability and driving factors. J. Mar. Syst. 2021, 213, 103461. [CrossRef] 
45. Yunev, O.A.; Vedernikov, V.I.; Basturk, O.; Yilmaz, A.; Kideys, A.E.; Moncheva, S.; Konovalov, S.K. Long-term variations of surface chlorophyll a and primary production in the open Black Sea. Mar. Ecol. Prog. Ser. 2002, 230, 11-28. [CrossRef]

46. Mikaelyan, A.S.; Chasovnikov, V.K.; Kubryakov, A.A.; Stanichny, S.V. Phenology and drivers of the winter-spring phytoplankton bloom in the open Black Sea: The application of Sverdrup's hypothesis and its refinements. Prog. Oceanogr. 2017, 151, 163-176. [CrossRef]

47. Kubryakov, A.A.; Bagaev, A.V.; Stanichny, S.V.; Belokopytov, V.N. Thermohaline structure, transport and evolution of the Black Sea eddies from hydrological and satellite data. Prog. Oceanogr. 2018, 167, 44-63. [CrossRef]

48. Kubryakov, A.A.; Mikaelyan, A.S.; Stanichny, S.V. Extremely strong coccolithophore blooms in the Black Sea: The decisive role of winter vertical entrainment of deep water. Deep. Sea Res. Part I Oceanogr. Res. Pap. 2021, 125, 103554. [CrossRef]

49. Kopelevich, O.; Burenkov, V.; Sheberstov, S.; Vazyulya, S.; Kravchishina, M.; Pautova, L.; Silkin, V.; Artemiev, V.; Grigoriev, A. Satellite monitoring of coccolithophore blooms in the Black Sea from ocean color data. Remote Sens. Environ. 2014, 146, 113-123. [CrossRef]

50. Kiselev, I.A. Plankton of Seas and Continental Basins; Nauka: St. Petersburg, Russia, 1969; p. 657. (In Russian)

51. Moncheva, S.; Parr, B. Manual for Phytoplankton Sampling and Analysis in the Black Sea. 2010. Available online: http: //www.blacksea-commission.org (accessed on 15 October 2021).

52. Tomas, C.R. (Ed.) Identifying Marine Phytoplankton; Academic Press: San Diego, CA, USA, 1997; p. 858.

53. Throndsen, J.; Hasle, G.R.; Tangen, K. Norsk Kystplanktonflora; Almater Forlag AS: Oslo, Norway, 2003 ; p. 341.

54. Hillebrand, H.; Durselen, C.; Kirschtel, D.; Pollingher, U.; Zohary, T. Biovolume calculation for pelagic and benthic microalgae. J. Phycol. 1999, 35, 403-424. [CrossRef]

55. Tyrrell, T.; Merico, M. Emiliania huxleyi: Bloom observations and the conditions that induce them. In Coccolithophores from Molecular Processes to Global Impact; Thierstein, H.R., Young, J.R., Eds.; Springer: Berlin/Heidelberg, Germany, $2004 ;$ pp. 75-97.

56. Kopelevich, O.V.; Burenkov, V.I.; Sheberstov, S.V.; Vazyulya, S.V.; Zavialov, S.P. Bio-optical characteristics of the Russian Seas from satellite ocean color data of 1998-2010. In Proceedings of the YI International Conference "Current Problems in Optics of Natural Waters (ONW 20011)", St. Petersburg, Russia, 6-9 September 2011; pp. 181-182.

57. Stanichnaya, R.G.; Stanichny, S.V.; Arashkevich, E.G. Regionally adapted algorithm for the recovery of chlorophyll aconcentration for the Black Sea, analysis of the reasonsfor the difference between satellite and contact data. Curr. Probl. Remote Sens. Earth Space 2020, 17, 29-37.

58. Carlson, D.F.; Muscarella, P.A.; Gildor, H.; Lipphardt, B.L., Jr.; Fredj, E. How useful are progressive vector diagrams for studying coastal ocean transport? Limnol. Oceanogr. 2010, 8, 98-106. [CrossRef]

59. Zatsepin, A.G.; Kremenetskiy, V.V.; Piotoukh, V.B.; Poyarkov, S.G.; Ratner, Y.B.; Soloviev, D.M.; Stanichnaya, R.G.; Stanichny, S.V.; Yakubenko, V.G. Formation of nearshore current in the Black Sea due to spatial non-uniformity of wind impact on the upper mixed layer. Oceanology 2008, 48, 1-17.

60. Ivanov, V.A.; Belokopytov, V.N. Oceanography of the Black Sea; NAS of Ukraine Marine Hydrophysical Institute: Sevastopol, Crimea, 2011; p. 209. (In Russian)

61. Finenko, Z.; Suslin, V.; Kovaleva, I. Seasonal and long-term dynamics of the chlorophyll concentration in the Black Sea according to satellite observations. Oceanology 2014, 54, 596-605. [CrossRef]

62. Dennman, K.L.; Gargett, A.E. Time and space scales of vertical mixing and advection of phytoplankton in the upper ocean. Limnol. Oceanogr. 1983, 28, 801-815. [CrossRef]

63. Pan, G.; Chai, F.; Tang, D.; Wang, D. Marine phytoplankton biomass responses to typhoon events in the South China Sea based on physical-biogeochemical model. Ecol. Model. 2017, 356, 38-47. [CrossRef]

64. Liu, Y.; Tang, D.; Evgeny, M. Chlorophyll Concentration Response to the Typhoon Wind-Pump Induced Upper Ocean Processes Considering Air-Sea Heat Exchange. Remote Sens. 2019, 11, 1825. [CrossRef]

65. Sverdrup, H.U. On conditions for the vernal blooming of phytoplankton. J. Cons. Int. Explor. Mer. 1953, 18, 287-295. [CrossRef]

66. Chiswell, S.M. Annual cycles and spring blooms in phytoplankton: Don't abandon Sverdrup completely. Mar. Ecol. Prog. Ser. 2011, 443, 39-50. [CrossRef]

67. Lindemann, C.; John, M.A.S. A seasonal diary of phytoplankton in the North Atlantic. Front. Mar. Sci. 2014, 1, A37. [CrossRef]

68. Gohin, F.; Bryère, P.; Griffiths, J.W. The exceptional surface turbidity of the North-West European shelf seas during the stormy 2013-2014 winter: Consequences for the initiation of the phytoplankton blooms? J. Mar. Syst. 2015, 148, 70-85. [CrossRef]

69. Ueyama, R.; Monger, B.C. Wind-induced modulation of seasonal phytoplankton blooms in the North Atlantic derived from satellite observations. Limnol. Oceanogr. 2005, 50, 1820-1829. [CrossRef]

70. Titov, V.B. The Effect of the Long-Term Variations in Climate Conditions on the Hydrological Structure and Ecology of the Black Sea. Water Resour. 2004, 31, 369-375. [CrossRef]

71. Sukhanova, I.N.; Mikaelyan, A.S.; Georgieva, L.V. Spatial distribution and temporal variations of phytoplankton in the Black Sea (March-April 1988) during the spring bloom period. In Studies of Phytoplankton Using Monitoring System in the Baltic Sea and Other Seas of the USSR; Tsyban, A.V., Ed.; Gidromet: Moscow, Russia, 1991; pp. 135-152. (In Russian)

72. Eker-Develi, E.; Kideys, A.E. Distribution of phytoplankton in the southern Black Sea in summer 1996, spring and autumn 1998. J. Mar. Syst. 2003, 39, 203-211. [CrossRef]

73. Sommer, U.; Gliwicz, Z.M.; Lampert, W.; Duncan, A. The PEG-model of seasonal succession of planktonic events in fresh waters. Arch. Hydrobiol. 1986, 106, 433-471. 
74. Siegel, D.A.; Doney, S.C.; Yoder, J.A. The North Atlantic spring phytoplankton bloom and Sverdrup's critical depth hypothesis. Science 2002, 296, 730-733. [CrossRef] [PubMed]

75. Sommer, U.; Adrian, R.; De Senerpont, D.L.; Elser, J.J.; Gaedke, U.; Ibelings, B.; Jeppesen, E.; Lürling, M.; Molinero, C.J.; Mooij, W.M.; et al. The Plankton Ecology Group (PEG) Model: Mechanisms driving plankton succession. Annu. Rev. Ecol. Evol. Syst. 2012, 43, 429-448. [CrossRef]

76. Behrenfeld, M.J. Abandoning Sverdrup's critical depth hypothesis on phytoplankton blooms. Ecology 2010, 91, 977-989. [CrossRef]

77. Taylor, J.R.; Ferrari, R. Shutdown of turbulent convection as a new criterion for the onset of spring phytoplankton blooms. Limnol. Oceanogr. 2011, 56, 2293-2307. [CrossRef]

78. Behrenfeld, M.J.; Boss, E.S. Resurrecting the Ecological Underpinnings of Ocean Plankton Blooms. Annu. Rev. Marine. Sci. 2014, 6 , 167-194. [CrossRef]

79. Arkhipkin, V.S.; Gippius, F.N.; Koltermann, K.P.; Surkova, G.V. Wind waves in the Black Sea: Results of a hind cast study. Nat. Hazards Earth Syst. Sci. 2014, 14, 2883-2897. [CrossRef]

80. Wirtz, K.W. Who is eating whom? Morphology and feeding type determine the size relation between planktonic predators and their ideal prey. Mar. Ecol. Prog. Ser. 2012, 445, 1-12. [CrossRef]

81. Stolte, W.; Riegman, R. A model approach for size-selective competition of marine phytoplankton for fluctuating nitrate and ammonium. J. Phycol. 1996, 32, 732-740. [CrossRef]

82. Klausmeier, C.A.; Litchman, E.; Daufresne, T.; Levin, S.A. Optimal nitrogen-to-phosphorus stoichiometry of phytoplankton. Nature 2004, 429, 171-174. [CrossRef] [PubMed]

83. Litchman, E.; Klausmeier, C.A.; Yoshiyama, K. Contrasting size evolution in marine and freshwater diatoms. Proc. Nat. Acad. Sci. USA 2009, 106, 2665-2670. [CrossRef]

84. Abakumov, A.I.; Silkin, V.A.; Pautova, L.A. Biomass dynamics of the phytoplankton under impact of the nutrient. Procedia Environ. Sci. 2011, 8, 105-110. [CrossRef]

85. Mikaelyan, A.S.; Kubryakov, A.A.; Silkin, V.A.; Pautova, L.A.; Chasovnikov, V.K. Regional climate and patterns of phytoplankton annual succession in the open waters of the Black Sea. Deep-Sea Res. Part I 2018, 142, 44-57. [CrossRef]

86. Morel, A.; Bricaud, A. Theoretical results concerning light absorption in a discrete medium, and application to specific absorption of phytoplankton. Deep Sea Res. 1981, 28, 1375-1393. [CrossRef]

87. Finkel, Z.V.; Irwin, A.J. Modeling size-dependent photo synthesis: Light absorption and the allometric rule. J. Theor. Biol. 2000, 204, 361-369. [CrossRef] [PubMed]

88. Finkel, Z.V. Light absorption and size scaling of light-limited metabolism in marine diatoms. Limnol. Oceanogr. 2001, 46, 86-94. [CrossRef]

89. Finkel, Z.V.; Irwin, A.J.; Schofield, O. Resource limitation alters the $\frac{3}{4}$ size scaling of metabolic rates in phytoplankton. Mar. Ecol. Prog. Ser. 2004, 273, 269-279. [CrossRef]

90. Yunev, O.A.; Carstensen, J.; Stelmakh, L.V.; Belokopytov, V.N.; Suslin, V.V. Reconsideration of the phytoplankton seasonality in the open Black Sea. Limnol. Oceanogr. Lett. 2021, 6, 51-59. [CrossRef]

91. Duysens, L.N.M. The flattening of the absorption spectra of suspensions as compared to that of solutions. Biochim. Biophys. Acta 1956, 19, 1-12. [CrossRef]

92. Key, T.; McCarthy, A.; Campbell, D.A.; Six, C.; Roy, S.; Finkel, Z.V. Cell size trade-offs govern light exploitation strategies in marine phytoplankton. Env. Microbiol. 2010, 12, 95-104. [CrossRef] [PubMed]

93. Agusti, S. Allometric scaling of light absorption and scattering by phytoplankton cells. Can. J. Fish. Aquat. Sci. 1991, 48, 763-767. [CrossRef] 